\title{
Using local ecological knowledge to locate the western long-beaked echidna Zaglossus bruijnii on the Vogelkop Peninsula, West Papua, Indonesia
}

\author{
Freddy PatTISELANNO, IRIANSUL \\ Paul A. Barnes and Agustina Y. S. ARobaya
}

\begin{abstract}
The Critically Endangered western long-beaked echidna Zaglossus bruijnii is believed to be distributed throughout the Vogelkop Peninsula in the Indonesian Province of West Papua, but there had formerly been no confirmed sightings of the species since the 1980s. We aimed to establish whether the species survives in this area. Fieldwork was carried out during January-April 2018 in Tambrauw Regency in the north and Teluk Bintuni Regency in the south. Fieldwork involved informal interviews with people, identified through chain referral sampling, who were knowledgeable about local animals and plants. Interviewees were asked about their knowledge of the western long-beaked echidna and if they had encountered them locally. Thirteen interviewees were familiar with the species and we were able to confirm informant records of one individual in Tambrauw Regency and three in Teluk Bintuni Regency. Measurements of the three individual echidnas in Teluk Bintuni Regency corroborated previous descriptions of the species. Interviewees described how echidnas are often seen in the forests around villages, especially during the wet season during January-April, when their foraging signs are easy to distinguish from those of other animals. These four records of the western long-beaked echidna are the first confirmed sightings since the 1980s. They suggest the species persists on the Vogelkop Peninsula, and anecdotal information from the interviewees suggests the species remains common. Nevertheless, detailed
\end{abstract}

Freddy PatTiselanno* $†$ (Corresponding author, (1) orcid.org/0000-0002-32075934, f.pattiselanno@unipa.ac.id) Laboratory of Wildlife and Tropical Animal, Faculty of Animal Sciences Universitas Papua, Jl. Gunung Salju Amban Manokwari, West Papua 98314, Indonesia

IRIANsul Animal Husbandry and Veterinary Medicine West Papua Provincial Office, Manokwari, Papua Barat, Indonesia

PaUl A. BARnes $\$$ (@ orcid.org/0000-0001-9990-5800) EDGE of Existence Programme, Zoological Society London, London, UK

Agustina Y. S. ARobaya (10 orcid.org/0000-0003-4602-4289) Faculty of Forestry Universitas Papua, Manokwari, Papua Barat, Indonesia

${ }^{*}$ Also at: College of Science and Engineering, James Cook University, Cairns, Australia

$\dagger$ Also at: Biodiversity Research Centre, Universitas Papua, Manokwari, Papua Barat, Indonesia

¥Also at: Department of Anthropology, University College London, London, UK

Received 28 October 2020. Revision requested 21 January 2021.

Accepted 12 March 2021. First published online 29 November 2021. systematic surveys are required before any assertion about the status of this species can be made with confidence.

Keywords Critically Endangered, Indonesia, local ecological knowledge, New Guinea, West Papua, western long-beaked echidna, Zaglossus bruijnii

The five extant species of egg-laying mammal include 1 four echidna species in the family Tachyglossidae and the platypus Ornithorhynchus anatinus in the family Ornithorhynchidae. These species are exclusive to Tasmania, Australia and New Guinea, which lie on a continental shelf that has been periodically connected at times of low sea level. The four echidna species include the short-beaked echidna Tachyglossus aculeatus and three allopatric long-beaked echidna species of the genus Zaglossus (Flannery \& Groves, 1998): the eastern long-beaked echidna Z. bartoni, Attenborough's long-beaked echidna $Z$. attenboroughi, and the western long-beaked echidna Z. bruijnii. Attenborough's and the western long-beaked echidnas are recognized as top priorities for global mammal conservation by the Zoological Society of London's Edge of Existence programme because of their unique evolutionary history and Critically Endangered status. Currently, the three long-beaked echidnas are known only from New Guinea and a few small offshore islands, although there is speculation that a remnant population of the western longbeaked echidna may persist in the West Kimberley region of Australia (Helgen et al., 2012). All three long-beaked echidnas are threatened across their range and there is little information about their status, and thus making even rudimentary decisions concerning their conservation is challenging.

Long-beaked echidnas are threatened by hunting, which was formerly carried out for subsistence throughout New Guinea (Pattiselanno, 2006; Leary et al., 2016; Pattiselanno \& Koibur, 2018). More recently, habitat loss as a result of logging, agriculture, industrial plantations, and mining also pose threats, not least because they increase opportunity for more intensive hunting as new areas of forest are made accessible to settlers and temporary residents (Pattiselanno \& Koibur, 2018; Gaveau, 2019). The western long-beaked echidna is believed to be distributed throughout the Vogelkop Peninsula in the Indonesian Province 
TABLE 1 Confirmed records of the western long-beaked echidna Zaglossus bruijnii in West Papua, Indonesia (Fig. 1). Record no. 1 was a carcass; records 2-4 were alive.

\begin{tabular}{llllll}
\hline & & Nearest & & $\begin{array}{l}\text { Weight } \\
\text { Record }\end{array}$ & $\begin{array}{l}\text { Body } \\
\text { length } \\
(\mathrm{cm})\end{array}$ \\
\hline 1 & $\begin{array}{l}\text { Tambrauw } \\
\text { village }\end{array}$ & Warmandi & 15 Jan. 2018 & & \\
2 & $\begin{array}{l}\text { Teluk } \\
\text { Bintuni } \\
3\end{array}$ & Wasian & 22 Feb. 2018 & 8.23 & 68 \\
& $\begin{array}{l}\text { Teluk } \\
\text { Bintuni }\end{array}$ & Tembuni & 2 Mar. 2018 & 12.52 & 73 \\
& $\begin{array}{l}\text { Teluk } \\
\text { Bintuni }\end{array}$ & $\begin{array}{l}\text { Bangun } \\
\text { Mulia }\end{array}$ & 20 Apr. 2018 & 6.43 & 63 \\
\hline
\end{tabular}

of West Papua and potentially on the offshore islands of Salawati, Batanta and Waigeo (Flannery, 1995; Helgen, 2007; Leary et al., 2016), although the degree of its persistence across this range is unknown. There have been no confirmed records since the 1980s (Leary et al., 2016) and we have been unable to identify the source of the 1980 os records on which the IUCN Red List assessment is based. Since this time there has been an anecdotal report from a local inhabitant interviewed in Ayamaru in Meybrat Regency who, in 1995, claimed the species can be found across the Regency, and that it lives in the surroundings of Mapura/Suwiam and between Mapura/Suwai and Kokas (a village close to Aiawasi) and around Aiawasi. It is rare on the other side of the lake (Ayamaru, Kartapura/Men, Kambuaya)' (Pasveer, 2004, p. 407).

To investigate whether the western long-beaked echidna survives in West Papua, we visited the village of Imbuan in Tambrauw Regency, on the north coast, in January 2018, and the villages of Tembuni, Araisum, Mogoi Baru and Bangun Mulia in Teluk Bintuni Regency during FebruaryApril 2018. These five villages are adjacent to forest habitat that is potentially suitable for the western long-beaked echidna. Interviewees (four in Tambrauw and nine in Teluk Bintuni) were identified through chain referral sampling. We interviewed people informally, seeking to speak with those who were knowledgeable about local animals and plants, in particular hunters or retired hunters. We asked informal, open-ended questions about the western long-beaked echidna and whether the interviewees had encountered it locally. Interviewees were asked to describe the species and its behaviour and signs, locations where they had seen it, and any other information they thought was pertinent.

The 13 interviewees were familiar with echidnas and described sightings within the previous year. We confirmed one record in Tambrauw Regency (record 1, Table 1), from discussions with a hunter in Imbuan, who explained how he had accidentally caught an echidna on 15 January, two days before our interview, in a trap intended to catch deer and wild pigs, near Warmandi. The hunter described the hunting ground where the echidna was caught as a flat, muddy, open area close to a stream, $2-3 \mathrm{~km}$ from the settlements, at 120-170 $\mathrm{m}$ altitude, and noted that the distinctive echidna foraging signs (imprints of nose-pokes) are regularly encountered in these areas. The hunter had taken the carcass to Imbuan and we confirmed that it was a western longbeaked echidna.

We confirmed three records, all alive, in Teluk Bintuni Regency (Plate 1), and were able to take measurements (Table 1). These individuals were being retained for sale.

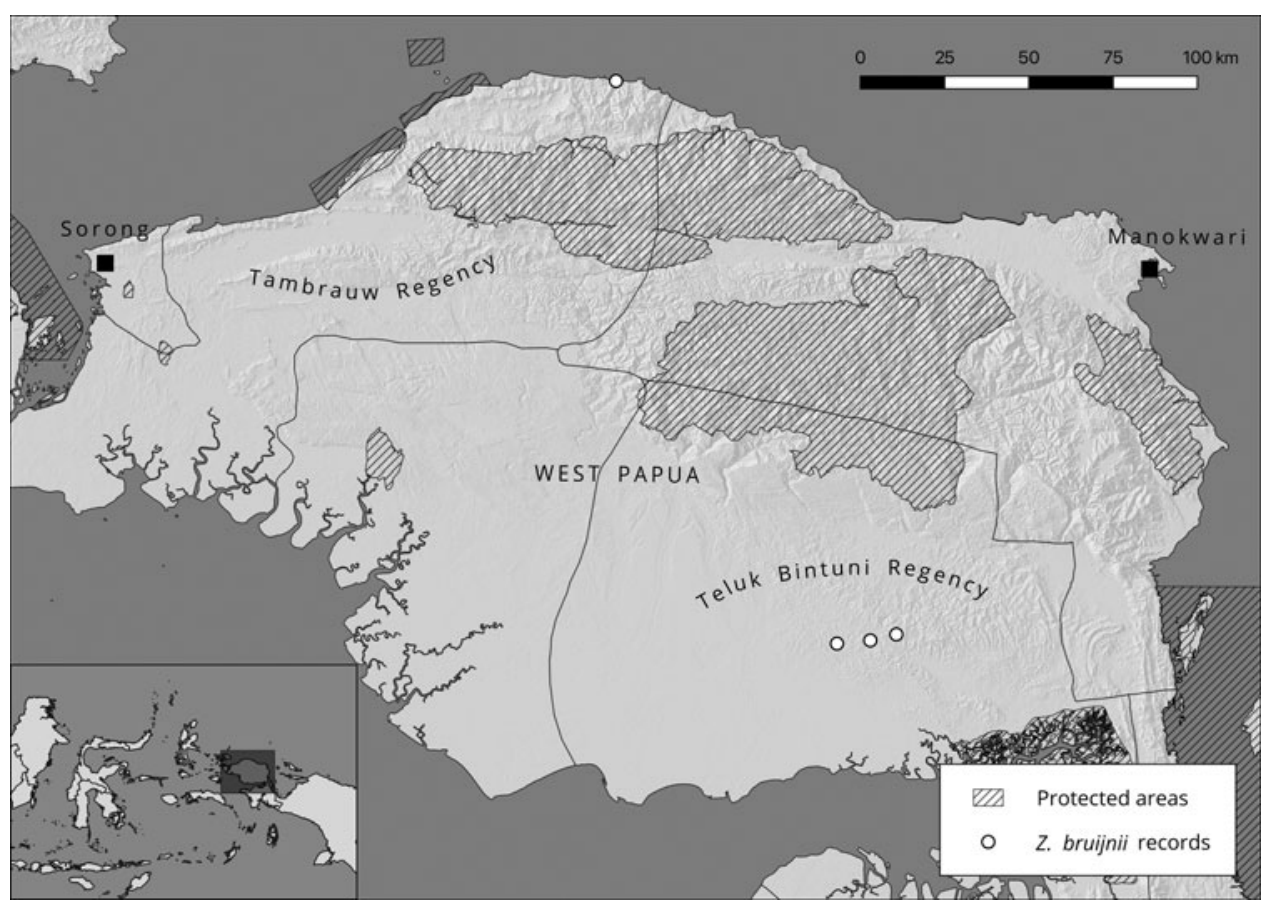

FIG. 1 Location of the four confirmed records of the western long-beaked echidna Zaglossus bruijnii, one in the Tambrauw and three in the Teluk Bintuni Regencies of West Papua, Indonesia. 


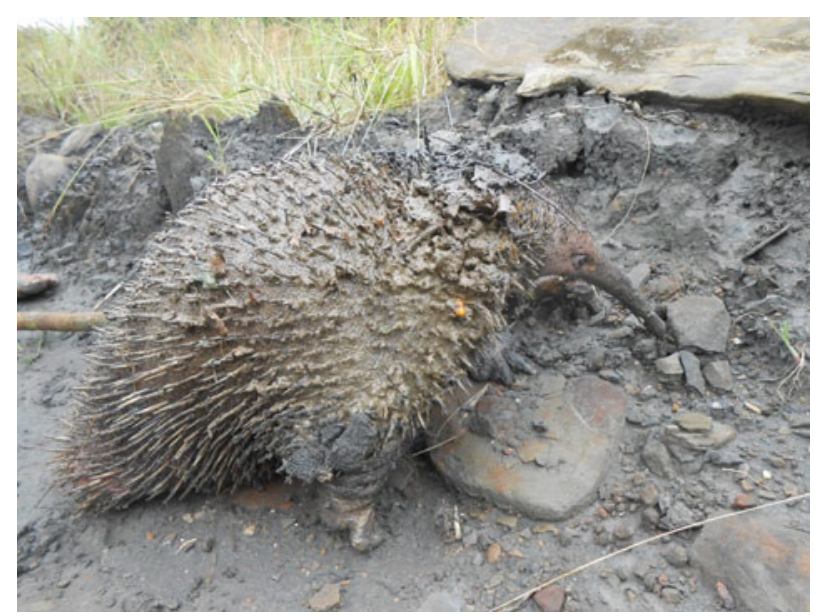

PLATE 1 Living western long-beaked echidna Zaglossus bruijnii encountered near Bangun Mulia village, Teluk Bintuni Regency (record 4 in Table 1 ).

Record 2 was from an interviewee who found the echidna near Wasian, adjacent to the river. Record 3 was captured by two local hunters from Bangun Mulia and Mogoi Baru, south-west of Tembuni adjacent to the Sidua River at $57 \mathrm{~m}$ altitude. Record 4 was found by a hunter from Araisum, in swamp forest close to Bangun Mulia, while checking hunting traps. The typical habitat in which these three individuals were found was lowland forest close to small creeks flowing into the Sidua River. The most common tree species in these areas are merbau Intsia bijuga, pulai Alstonia scholaris, nyatoh Palaqium sp. and medang Litsea timoriana. The sites were muddy, with numerous fallen and rotting trees and with the forest floor covered by scrub, forage and hollow logs, which are suitable for echidna burrows.

These records of the western long-beaked echidna were from hunters or retired hunters who reported characteristics that corroborate the description of the species by Flannery (1995). The hunters described the fur colour as dark brown to black with spines on the flanks and back, with a long downward curving nose, and feet with three claws. According to the interviewees in the Teluk Bintuni Regency, the western long-beaked echidna is easy to find, especially during the wet season in January-April when the ground is flooded and muddy. At this time the foraging signs (imprints of nose-pokes) are easy to distinguish from the signs of other animals and are often observed in forests around the villages. The interviewees also described to us some of the beliefs and taboos concerning echidna hunting and consumption: people are not permitted to shout or use foul language while searching for echidnas in the forest, and not all people are permitted to consume echidna meat. In particular, children under 10 years of age are forbidden to consume the meat as it is believed to have negative effects on their physical development.
These four records of the western long-beaked echidna, obtained with the help of the local ecological knowledge of the people we interviewed, are the first confirmed sightings of this species on the Vogelkop Peninsula since the 1980s. Anecdotal information from the interviewees suggests the species remains abundant. Nevertheless, detailed systematic surveys are required before any assertion about the status of this species can be made with confidence.

Acknowledgements We thank hunters in Abun District of Tambrauw Regency for providing information on the western longbeaked echidna; the local government and the people of Tembuni District, Teluk Bintuni, for their assistance and for granting us permission to conduct this study; and interviewees in Wasian, Tembuni and Bangun Mulia of Teluk Bintuni Regency for allowing us to interview them and identify, measure and weigh the three living echidnas.

Author contributions Fieldwork: FP, I, AYSA; writing: FP, PAB.

\section{Conflicts of interest None.}

Ethical standards This research followed the ethical guidelines of the Association of Social Anthropologists of the UK and Commonwealth (ASA, 2011). The study received approval from the James Cook University Human Research Ethics Committee (Approval number: H4203) and from the Biodiversity Research Centre of Universitas Papua (Research Permit No 08/UN42.15.2/KP/ VIII/2018), and otherwise abided by the Oryx guidelines on ethical standards.

\section{References}

ASA (Association of Social Anthropologists) (2011) Ethical Guidelines for Good Research Practice. theasa.org/ethics/guidelines. html [Accessed 12 July 2021].

Flannery, T.F. (1995) Mammals of New Guinea. Reed Books, Chatsworth, Australia.

Flannery, T.F. \& Groves, C.P. (1998) A revision of the genus Zaglossus (Monotremata, Tachyglossidae), with description of new species and subspecies. Mammalia, 62, 367-396.

Gaveau, D. (2019) Drivers of Forest Loss in Papua and West Papua. Center for International Forestry, Bogor, Indonesia.

Helgen, K.M. (2007) A taxonomic and geographical overview of the mammals of Papua. In The Ecology of Papua: Part One (eds A.J. Marshall \& B.M. Beehler), pp. 689-749. Periplus Editions, Singapore.

Helgen, K.M., Miguez, R.P., James, L.K. \& Lauren, E.H. (2012) Twentieth century occurrence of the long-beaked echidna Zaglossus bruijnii in the Kimberley region of Australia. Zookeys, 255, 103-132.

Leary, T., Seri, L., Flannery, T., Wright, D., Hamilton, S., Helgen, K. et al. (2016) Zaglossus bruijnii. In The IUCN Red List of Threatened Species 2016. dx.doi.org/10.2305/IUCN.UK.2016-2. RLTS.T23179A21964204.en [accessed 2 February 2017].

Pasveer, J.M. (2004) The Djief Hunters, 26,ooo Years of Rainforest Exploitation on the Bird's Head of Papua, Indonesia: Modern Quaternary Research in Southeast Asia, Volume 17. CRC Press, Boca Raton, USA.

Pattiselanno, F. (2006) The wildlife hunting in Papua. Biota, $11,59-61$.

Pattiselanno, F. \& Koibur, J.F. (2018) Returns from Indigenous hunting in the lowland coastal forests of West Papua benefits threatened wildlife species. Jurnal Manajemen Hutan Tropika, 24, 46-50. 